\title{
Organic carbon and microbiome in tundra and forest-tundra permafrost soils, southern Yamal, Russia
}

\author{
Ivan Alekseev' (1), Aleksei Zverev ${ }^{1,2}$ \& Evgeny Abakumov ${ }^{1}$ (1) \\ ${ }^{1}$ Faculty of Biology, Department of Applied Ecology, Saint Petersburg State University, Saint Petersburg, Russia; \\ ${ }^{2}$ All-Russian Research Institute for Agricultural Microbiology, Saint Petersburg, Russia
}

\section{Abstract}

Permafrost soils differ significantly from other soils because they serve as a huge reservoir for organic carbon accumulated during the Quaternary Period, which is at risk of being released as the Arctic warms. This study aimed to characterize existing carbon pools, delineate possible mineralization risks of soil organic matter and assess microbial communities in the tundra and forest-tundra permafrost soils of the southern Yamal region of Russia. The profile distribution of carbon, nitrogen and the C:N ratio showed non-gradual changes with depth due to the manifestation of cryopedogenesis in soil profiles, which lead to cryogenic mass transfer. Mean carbon stocks for the study area were $7.85 \pm$ $2.24 \mathrm{~kg} \mathrm{~m}^{-2}(0-10 \mathrm{~cm}$ layer $), 14.97 \pm 5.53 \mathrm{~kg} \mathrm{~m}^{-2}(0-30 \mathrm{~cm})$ and $23.99 \pm 8.00$ $\mathrm{kg} \mathrm{m}^{-2}(0-100 \mathrm{~cm})$. The analysis of the humus type revealed a predominance of fulvic type and low-molecular-weight fragments in the fulvic acid fraction, which indicates high mineralization risk of humic substances under Arctic warming conditions. The taxonomic analysis of soil microbiomes revealed 48 bacterial and archaeal phyla, among which proteobacteria $(27 \%)$ and actinobacteria $(20 \%)$ were predominant. The $\mathrm{pH}$ range and nitrogen accumulation were the main environmental determinants of microbial community diversity and composition in the studied soils.
\end{abstract}

\section{Keywords}

Arctic ecosystems; climate change; pedogenesis; soil organic carbon; soil microbial communities; Yamal Peninsula

\section{Correspondence \\ Ivan Alekseev, Saint Petersburg State University, Faculty of Biology, Department of Applied Ecology, 199034, 16th Line of Vasilevsky Island 29, Saint Petersburg, Russia. E-mail: alekseevivan95@gmail.com}
Abbreviations
Cha: Cfa: ratio of carbon in humic acids to carbon in fulvic acids
OTU: operational taxonomic unit
PCA: principal component analysis
QIIME: quantitative insights into microbial ecology
SD: standard deviation
SOC: soil organic carbon

\section{Introduction}

Soils play a crucial role in the accumulation, transformation, redistribution and migration of various chemical compounds and elements in polar ecosystems (Goryačkin 2014). Soils serve as a linkage between the small and large geological cycles of matter and energy fluxes (Tarnocai et al. 2009; Zubrzycki et al. 2014). Permafrostaffected soils occupy a significant area-approximately 8.6 million $\mathrm{km}^{2}$, about $27 \%$ of all land areas north of $50^{\circ} \mathrm{N}$ (Tarnocai et al. 2009). Undergoing low average temperatures and extreme interannual temperature differences, these soils have accumulated vast pools of organic matter during the Quaternary Period (Smith \& Veldhuis 2004; Zimov et al. 2006; Zubrzycki et al. 2013). Permafrost-affected soils serve as a massive reservoir of organic carbon: up to $1024 \mathrm{Pg}$ in the upper $3 \mathrm{~m}$ (Tarnocai et al. 2009). Arctic permafrost-affected soils differ significantly from soils in other geographical regions because of the storage of this enormous pool of carbon in the active layer compared to the annual production by plant biomass (McGuire et al. 2009; Hugelius et al. 2014; Köchy et al. 2015). Permafrost areas in the Northern Hemisphere contain approximately $30-40 \%$ of the global soil carbon pool within the 3-m soil layer, while they comprise only $15 \%$ of the global land surface and $10-20 \%$ of the global vegetation carbon pool (McGuire et al. 2009; Hugelius et al. 2014). Taking into account that permafrost-affected soils serve as a significant reservoir of organic matter and that climate change is already proving to be particularly manifested in polar regions, permafrost-affected landscapes are considered one of the most critical cryosphere elements within the climate system (Hugelius et al. 2014; Zubrzycki et al. 2014). Qualitative and quantitative studies of soil organic matter and soil microbial communities are crucial as the massive amount of organic carbon stored in permafrost soils might be vulnerable to priming, caused by the increasing availability of plant-derived organic compounds with rising temperatures.

Because the depth of the upper boundary of permafrost varies markedly from place to place, so does the structure of the soil in the active layer and the interactions between soil and permafrost (Gubin \& Lupachev 2008). Thus, the widespread occurence of microcomposition 
components that are not correlated with modern bioclimatic conditions testifies to the polygenetic state of soils. The nano- and microrelief of permafrost-affected landscapes is important: microdepressions accumulate more organic matter, while microelevations accumulate less organic matter (Lupachev et al. 2016).

Taking into account that most tundra plant communities are limited in nitrogen, the C:N ratio may serve as a control of plant response to climate change (Schimel et al. 1996). To predict how soil will respond to climate change in terms of releasing carbon dioxide and nitrogen, it is necessary to know how much biologically available carbon and nitrogen are in pools of organic matter and their dynamics. A number of studies of carbon and nitrogen mineralization in permafrost-affected soils have revealed the primary controls on it: temperature, soil water and quality of organic matter inputs (Nadelhoffer et al. 1992; Schimel et al. 1996).

There are many knowledge gaps regarding the organic matter in permafrost-affected soils, including qualitative assessments of organic matter, its distribution in permafrost-affected landscapes and soils, carbon and nitrogen pools, their dynamics and stabilization, and climate-relevant gas release from the soil. This list of topics is not exhaustive for adequate assessment of the current state of permafrost-affected regions and their fate in the face of predicted climate change. A better understanding and modelling of the Earth's climate system requires improving our knowledge of carbon, water and energy exchange between terrestrial ecosystems and the atmosphere (Parry et al. 2007).

The quality and quantity of estimations of SOC pools in the Russian Arctic are inconsistent and insufficient. Incongruities in the ways the data have been collected (Schepaschenko et al. 2013), including differences in soil depths examined, and incomplete data are all issues. For example, soil bulk density is often very approximate and inadequate for a detailed assessment.

Our current understanding of ecosystem functioning is mainly expressed in terms of pools and fluxes. Hence, predictions of ecosystem functioning under varied environmental conditions and disturbances depend heavily on the accuracy of the linkages between conceptual pools of soil organic matter, estimating their capacity and calculating the rates and volume of the fluxes between the pools (Kuzyakov 2011).

Soil microbiomes play an essential role in the development of soil profiles and the implementation of soil biochemical processes (Wolińska et al. 2018). Microorganisms play a key role in decomposition of organic material, ensuring the cycling of nutrients and the formation of organic matter in the soil (Schütz et al. 2010; Wolińska et al. 2016).

Despite the very harsh environments of the Arctic, the diversity of its soil bacterial communities is as high as in other biomes. Soil microbial diversity in Arctic soils is likely to be driven by many environmental factors, including the soil's physical properties and nutrient availability. Permafrost-affected soils are characterized by the slow decomposition of organic matter, which is caused by a combination of the acid reactions of soils, low temperatures, functional limitations of the microbial communities performing mineralization, suppression of oxidase activity due to lack of oxygen and the presence of chemically complicated substrates with low nitrogen content (Freeman et al. 2001; Moore \& Basiliko 2006). Moreover, the basal respiration rate and productivity of plants are also affected and limited by the low level of available nitrogen (Kaiser et al. 2011). Studies of soil microbial communities and how the rate of organic matter decomposition in the soil responds to Arctic warming are important for improved climate system modelling.

The overall aim of this work was to assess existing carbon pools and microbial communities in soils formed in permafrost-affected landscapes of the Yamal region. The particular objectives of this work were: to estimate the level of organic carbon accumulation and evaluate the characteristics of soil carbon within the southern Yamal region; to investigate the main physical and chemical properties of natural permafrost-affected soils in regard to their influence on soil organic matter characteristics; and to evaluate soil microbiome composition and relationships between microbiome alpha-diversity indices and soil properties.

\section{Materials and methods}

\section{Fieldwork and soil sampling}

Soils were sampled in the Yamal region during the Yamal-Arctic-2015 (August 2015) and Yamal-Arctic-2016 (July-August 2017) expeditions. Supplementary materials (landscape photographs, soil temperatures from July 2016 to July 2017) were collected during the YamalArctic-2017 expedition. The area of study included six key plots in the southern tundra and forest-tundra zone (Fig. 1, Table 1). To expand the scientific understanding of SOC accumulation and microbiome composition in Arctic ecosystems, we analysed 156 soil samples from the transitional forest-tundra and tundra zone in the southern part of Yamal. Each of the studied site is $50 \times 50 \mathrm{~m}$ and included six sampling points. Soils were sampled at different depths in $20 \times 20 \mathrm{~cm}$ soil pits. The samples were stored in double sterile plastic bags, labelled and transported to the laboratory. For this study, we chose two sites located in the forest-tundra ecotone (surrounding the Salekhard and Khalyatalbey rivers), which are in the transitional zone between the Siberian taiga and the 


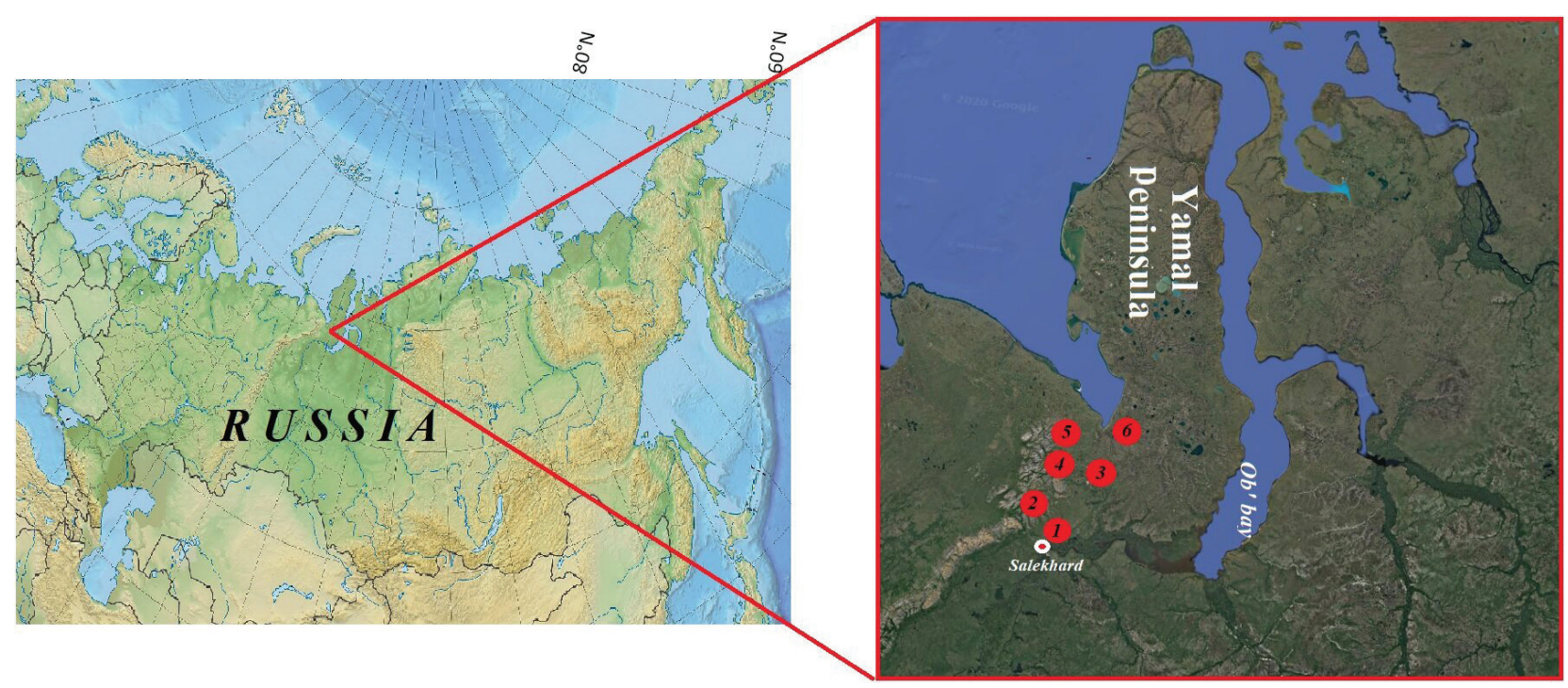

Fig. 1 Area of investigation in the western Siberian sector of the Russian Arctic and study sites: (1) vicinity of Salekhard; (2) the Polar Urals (Chyornaya Mountain and Kerdamon-Shor Valley); (3) Khalyatalbey River; (4) Bolshaya Hadata River; (5) Bolshoe Schuchie Lake; (6) Erkuta River.

tundra. Such ecotones are characterized by large ecosystem variability and are very sensitive to even small variations in environmental variables, and therefore serve as early indicators of the consequences of climate change at a larger scale (Hugelius \& Kuhry 2009).

The climate of the southern Yamal Peninsula is severe and continental. The radiation balance values are approximately $18-20 \mathrm{kcal} \mathrm{cm}^{-2}$ year $^{-1}$. Relative humidity in the entire peninsula is high $(70-90 \%)$ throughout the year, the result of low air temperatures and proximity to the cold waters of the Kara Sea (Dobrinskij 1995). The average precipitation is approximately $350-400 \mathrm{~mm}_{\text {year }}^{-1}$, and relative dryness of Arctic air masses means that only a small amount of precipitation falls in the northern part of the peninsula (Vlasov et al. 2014). The annual evaporation is not high (approximately $250 \mathrm{~mm}_{\text {year }}^{-1}$ ). The number of days with snow cover varies from 233 to 240, winter lasts 7-7.5 months, and the average temperature in January is $-23^{\circ} \mathrm{C}$ to $-25^{\circ} \mathrm{C}$. Spring is usually short ( 35 days) and cold, with dramatic weather changes and frequent returns of cold and frost. The growing season is 70 days. The average temperature of the warmest month is $+5^{\circ} \mathrm{C}$. Autumn is short, with maximal pressure gradient volatility, abrupt changes in temperature and frequent early frosts. The region is characterized by a cold and humid climate (Šijatov \& Mazepa 1995). The Yamal Peninsula has been described as region that is very sensitive to climate warming (Forbes \& Kumpula 2009). A $1-2^{\circ} \mathrm{C}$ increase in the average air temperature has been reported, which is significant for enhancing the rates of soil organic matter humification and the emission of climate-relevant gases to the atmosphere (McGuire et al. 2009). It should be reported that the summer seasons of 2016 and 2017 were extraordinarily warm for the southern Yamal region. The mean air temperature during fieldwork in July was about $+27-30^{\circ} \mathrm{C}$, which is much higher than the mean Arctic temperatures stated in the literature for recent decades. This coincides with the finding that various anthropogenic disturbances have increased summer temperatures in the Arctic, along with permafrost thaw and wildfires, and that landslides might lead to shrub expansion by creating mineral-rich soils favourable for shrubs (Racine et al. 2004; Walker et al. 2009; Lantz et al. 2010).

The landscape diversity of southern Yamal determines the peculiarities of geochemical flows, soil diversity, the functioning of the hydrological network and terrestrial element cycles (Fig. 2). In general terms, the soils of the southern Yamal Peninsula are mostly Histic Gleysols and Aquiturbic Cryosols in hydromorphic positions and Histic Podzols in autonomous positions. These soils are usually characterized by a low fertility level (low amount of nitrogen, phosphorus and potassium) as well as low cation exchange capacity, base saturation and acid intervals of $\mathrm{pH}$, and high exchangeable and hydrolytic acidity (Alekseev \& Abakumov 2018). The permafrost table depth varies between 70 and $120 \mathrm{~cm}$ in the studied area (Alekseev, Kostecki et al. 2017).

\section{Soil analyses}

The main soil parameters were determined using standard procedures. Values of $\mathrm{pH}$ in water and salt suspension 

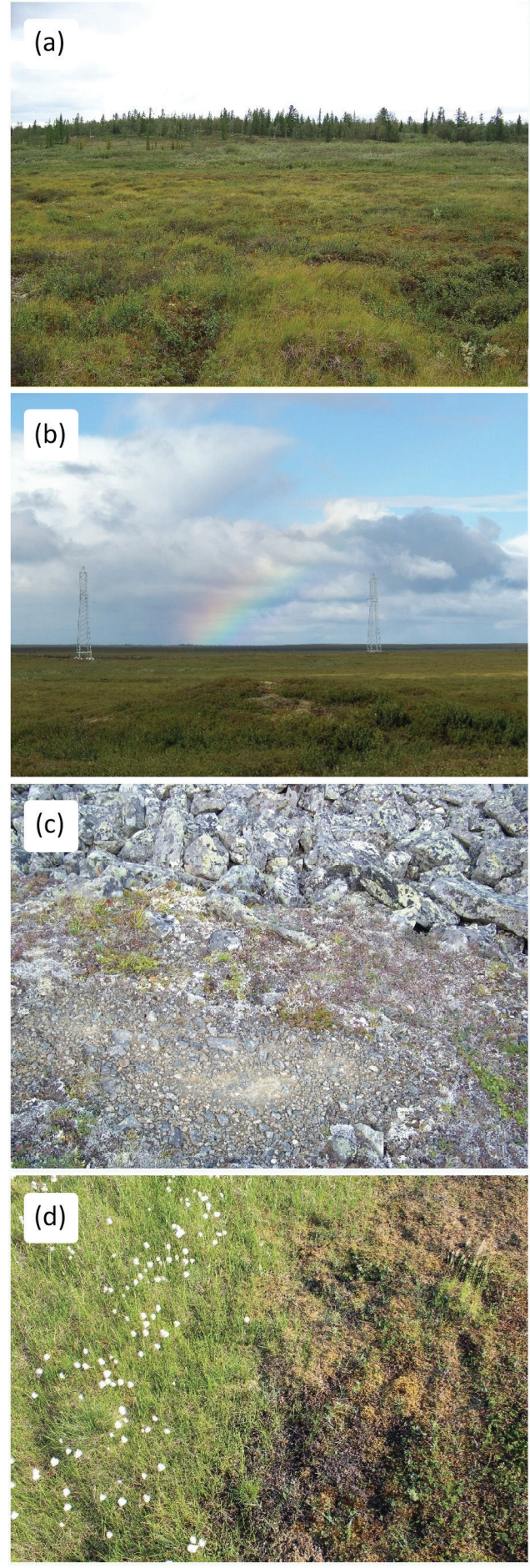

Fig. 2 Landscape diversity of the studied area: (a) forest-tundra site, wet hummock tundra combined with associations of larch forest (Larix sibirica) in the vicinity of Salekhard; (b) bulganniakh (pingo) in southern tundra (Khalyatalbery River); (c) non-sorted circle (frost boil) on the eastern slope of Chyornaya Mountain in the Polar Urals; (d) example of a combination of wet tundra (Eriophorum vaginatum as a dominant species) and spots with reduced vegetation (Erkuta River). were measured using a pH150 meter (1:2.5 soil:solution ratio, an accuracy of \pm 0.05 ). Exchangeable and hydrolytic acidity were measured by adding $\mathrm{KCl}$ and $\mathrm{NaCH}_{3} \mathrm{COO}$, respectively ( $1: 2.5$ soil:solution ratio). The basal respiration of the soil horizons was measured using $\mathrm{NaOH}$ traps in closed incubation jars: $\mathrm{CO}_{2}$ concentrations were measured in soil samples in an alkaline solution in a plastic container for 10 days (temperature $20^{\circ} \mathrm{C}$, moisture $60 \%$ to initial soil weight, an accuracy of $\pm 3 \%$; see Bailey et al. [2008] for details of the method). Carbon and nitrogen content were measured using a Vario Max element analyser (Elementar Analyse Systeme; accuracy of $\pm 0.05 \%$ for both carbon and nitrogen). Extraction of humic and fulvic acids for further Cha:Cfa analysis was performed according to the method suggested by Schnitzer (1982; an accuracy of $\pm 3 \%$ ). Particle-size distribution was analysed by the pipette-sedimentation method (Kačinskij 1970; accuracy of $\pm 3 \%$ ). To determine bulk density, samples were taken using the soil core method described by Hao et al. (2008). The studied soil profiles were morphometrically examined to assess the predominant soil-forming processes and soil horizons quantitatively. Soils were characterized in accordance with the Russian Soil Classification System, using appropriate soil horizons indices (Šišov et al. 2004).

Soil diagnostics were performed according to the Russian Soil Classification System (Šišov et al. 2004) and the World Reference Base for Soil Resources system (FAO 2015)

The SOC content $\left(\mathrm{kg} \mathrm{m}^{2}\right)$ was calculated according to the formula suggested by Tarnocai et al. (2009) for each soil type and soil layers of $0-10,0-30$ and $0-100 \mathrm{~cm}$ depths:

$$
\text { SOC content }=C \times \mathrm{BD} \times T \text {, }
$$

where $C$ is the organic carbon (\%weight), BD is the bulk density $\left(\mathrm{g} \mathrm{cm}^{-3}\right)$ and $T$ is the soil layer thickness $(\mathrm{cm})$.

\section{Microbial analyses}

Topsoil material $(0-10 \mathrm{~cm}$ depth) for DNA extraction was not ground before analyses. Samples were frozen and transported to the laboratory. DNA was extracted from 5.0 to $7.0 \mathrm{~g}$ of soil material using the PowerSoil DNA Isolation Kit (Mobio Laboratories), which included a bead-beating step, according to the manufacturer's specifications. Homogenization of the samples was performed using a Precellys 24 (Bertin Corp.) homogenizer at $6.5 \mathrm{~m} \mathrm{~s}^{-1}$, twice for $30 \mathrm{~s}$ each time. The purity and quantity of DNA were tested by electrophoresis in $0.5 \times \mathrm{TAE}$ buffer on $1 \%$ agarose. DNA concentrations were measured at $260 \mathrm{~nm}$ using a SpectroStar Nano (BMG Labtech) 
absorbance plate reader. The average DNA yield was 2-5 $\mu \mathrm{g}$ DNA, with concentrations between 30 and $50 \mathrm{ng}$ $\mu \mathrm{L}^{-1}$. The purified DNA templates were amplified with universal multiplex primers F515 5'-GTGCCAGCMGCCGCGGTAA-3' and R806 5'-GGACTACVSGGGTATCTAAT-3' (Bates et al. 2010), targeting the variable region V4 of bacterial and archaeal 16S rRNA genes. Each multiplex primer contained the adapter, 4-bp key (TCAG), 10-bp barcode and primer sequences. The expected length of the amplification product was $400 \mathrm{bp}$. Sequencing of the amplicon libraries was conducted using an Illumina MiSeq at the Genomic Technologies, Proteomics and Cell Biology Centre (All-Russia Research Institute for Agricultural Microbiology, Russia). The raw sequences were processed using the QIIME microbiome bioinformatics platform (Caporaso et al. 2010). Preliminary processing of the raw reads was performed using Trimmomatic software (Bolger et al. 2014). The multiplexed reads were first filtered for quality and grouped according to barcode sequences to reduce sequencing errors. Sequences were omitted from the analysis if they were less than $200 \mathrm{bp}$, had a quality score below 25 and contained uncorrectable barcodes, primers, ambiguous characters or a homopolymer length equal to or greater than $8 \mathrm{bp}$. All nonbacterial ribosomal sequences and chimeras were also removed from the libraries. Forward and reverse reads were paired by fastq-join (Aronesty 2013), and chimeras were removed by using the VSEARCH engine (Rognes et al. 2016). A representative set of sequences was chosen by selecting the most abundant sequence from each OTU. Representative sequences from each OTU were subjected to a naïve Bayesian rRNA Classifier (Wang et al. 2007) with a confidence level of $80 \%$ and aligned using a PyNast algorithm and Greengenes database (DeSantis et al. 2006). Aligned sequences were used to build a distance matrix with a distance threshold of 0.1 and a phylogenetic tree necessary for downstream analysis. OTU picking based on $97 \%$ sequence similarity was performed using the SILVA database version 132 closed-reference algorithm (Quast et al. 2014).

\section{Statistical analyses}

To estimate alpha diversity, indices for richness (observed species and Chaol) and evenness (Faith's index and Shannon evenness) were calculated. Observed OTUs estimate the total number of OTUs in a sample and work as species number in ecology. Phylogenetic diversity or Faith's index estimates the total length of branches in a phylogenetic tree. This index reveals the taxonomic structure of samples-whether they are on the same branch or on several distant branches. Shannon index is a complex metric with both evenness and richness components. Chaol is a nonparametric method for estimating the number of species in a community. The $t$-test was performed to verify the observed differences. The abundances of OTUs were compared between samples by calculating the median relative change values for all groups of replicates. A positive median indicates an increase in abundance, whereas a negative median can be considered evidence for a decline in abundance. A basic permutation test was used to infer significance, while a jackknife-like resampling approach was applied to test the stability of median estimates.

The results of the alpha-diversity calculation were submitted to PCA in order to determine the common relationships between the alpha-diversity of the microbiome and soil parameters at respective sites. For the PCA analysis, all data sets were normalized. Values of soil parameters and alpha-diversity indices of microbial communities were divided by their highest observed values. Correlation analysis was performed to study the relationships of various soil parameters with microbiome alpha-diversity indices. Statistical analyses were performed using JASP analytical software (JASP Team, Amsterdam University).

\section{Results and discussion}

\section{Morphometric characterization of soils}

The morphometric analysis (Table 2, Fig. 3) revealed that peat formation and accumulation, stagnification (gleyic), cryoturbation and podzolization are the main soil-forming processes. It should be noted that the thickness of Histic and Stagnic horizons depends very much on the moisture regime and permafrost table depth in microand meso-landscapes. Analysis of the data obtained revealed that the thickest horizons are those developed in over-moistening conditions in microdepressions of the landscape and cryogenic horizons.

The mean thickness of the Stagnic horizons was $19.7 \pm 2.7(23.4 \pm 2.5) \mathrm{cm}$ and of the Histic horizons, $9.9 \pm 2.1 \mathrm{~cm}$. On the basis of these results, we decided to estimate soil carbon pools not only from the reference layers of $0-30 \mathrm{~cm}$ and $0-100 \mathrm{~cm}$ (Hugelius et al. 2014 ) but also for $0-10 \mathrm{~cm}$, which reflects the characteristic depth of the predominant topsoil horizon, where most organic carbon is stored in the study area. Regarding the presence of sorted circles and their soils, in such forms of microrelief, Turbic Cryosols/Typic Cryozems with specific soil profiles usually develop. These soils consist of a weakly developed and thin litter horizon (O) thin grey-humus (AY) or raw-humus (AO) horizons (mean thickness $5.4 \pm 2.3 \mathrm{~cm}$ ) and thick cryogenic horizons (CR $25.0 \pm 7.4 \mathrm{~cm}$ ). In the floodplains of the Erkuta 
Table 1 Geographical description of the studied sites.

\begin{tabular}{|c|c|c|c|}
\hline Site & Geographical coordinates & Landscape description & Name of predominant soils WRBa/RSCS ${ }^{b}$ \\
\hline Vicinity of Salekhard & $\begin{array}{l}\mathrm{N} 66^{\circ} 27^{\prime} 26.7^{\prime \prime} \\
\mathrm{E} 67^{\circ} 34^{\prime} 48.0^{\prime \prime}\end{array}$ & $\begin{array}{l}\text { Southern tundra/forest-tundra, predominantly } \\
\text { flat relief complicated by thermokarst lakes and } \\
\text { bulganniakhs (pingos) }\end{array}$ & $\begin{array}{l}\text { Histic Stagnic Cryosol/Peat Gleyzem } \\
\text { underlain by permafrost }\end{array}$ \\
\hline $\begin{array}{l}\text { Polar Urals (Chyornaya } \\
\text { Mountain and Kerdamon- } \\
\text { Shor Valley) }\end{array}$ & $\begin{array}{l}\mathrm{N} 66^{\circ} 49^{\prime} 52.0^{\prime \prime} \\
\mathrm{E} 65^{\circ} 28^{\prime} 37.2^{\prime \prime}\end{array}$ & $\begin{array}{l}\text { Eastern macroslope of the Polar Urals. Slopes } \\
\text { are composed of colluvial material. Non-sorted } \\
\text { circles on slopes. Valleys are represented by wet } \\
\text { (hummock) tundra }\end{array}$ & $\begin{array}{l}\text { Turbic Cryosols/Typic Cryozem (on slopes) } \\
\text { Histic Stagnic Cryosol/Peat Gleyzem } \\
\text { underlain by permafrost (in valleys) }\end{array}$ \\
\hline Khalyatalbey River & $\begin{array}{l}\text { N } 67^{\circ} 28^{\prime} 14.6^{\prime \prime} \\
E 67^{\circ} 26^{\prime} 15.2^{\prime \prime}\end{array}$ & $\begin{array}{l}\text { Southern tundra/forest-tundra. Foothills of the } \\
\text { Polar Urals }\end{array}$ & $\begin{array}{l}\text { Histic Stagnic Cryosol/Peat Gleyzem } \\
\text { underlain by permafrost }\end{array}$ \\
\hline Erkuta River & 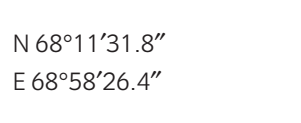 & $\begin{array}{l}\text { Southern tundra site, located on the first terrace } \\
\text { of Erkuta River. Relief is complicated by sorted } \\
\text { circles, ice-wedges }\end{array}$ & $\begin{array}{l}\text { Histic Cryosol/Peat eutrophic soil } \\
\text { underlain by permafrost }\end{array}$ \\
\hline Bolshaya Hadata River & $\begin{array}{l}\text { N } 67^{\circ} 35^{\prime} 17.8^{\prime \prime} \\
E 66^{\circ} 17^{\prime} 35.6^{\prime \prime}\end{array}$ & Southern tundra/forest-tundra site, hilly relief & $\begin{array}{l}\text { Histic Spodic Cryosol/Peat Podbur } \\
\text { underlain by permafrost }\end{array}$ \\
\hline Bolshoye Schuchie Lake & $\begin{array}{l}N 67^{\circ} 50^{\prime} 01.1^{\prime \prime} \\
E 66^{\circ} 23^{\prime} 17.0^{\prime \prime}\end{array}$ & $\begin{array}{l}\text { Southern tundra/forest-tundra. Colluvium. Relief is } \\
\text { also complicated by sorted and non-sorted circles }\end{array}$ & $\begin{array}{l}\text { Histic Spodic Cryosol/Peat Podbur } \\
\text { underlain by permafrost }\end{array}$ \\
\hline
\end{tabular}

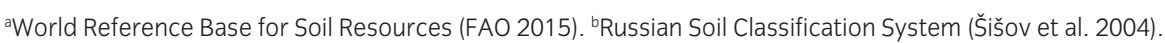

Table 2 Morphometric analysis of investigated soils.

\begin{tabular}{lc}
\hline Soil horizon (RSCS) & $\begin{array}{c}\text { Horizon thickness } \\
\text { (mean } \pm \mathrm{SD}, \mathrm{cm} \text { ) }\end{array}$ \\
\hline Topsoil horizons & \\
$\quad$ Grey humus (AY), litter (O), humus-litter (AO) & $5.4 \pm 2.3$ \\
$\quad$ Buried organic matter (H) & $5.5 \pm 3.5$ \\
Histic (TE) & $9.9 \pm 2.1$ \\
Eluvial horizons & \\
Strict eluvial (E) & $7.9 \pm 3.8$ \\
Eluvial (EL) & $8.8 \pm 0.52$ \\
Diagnostic horizons & \\
$\quad$ Iron-illuvial (BF) & $7.3 \pm 2.5$ \\
Cryogenic (CR) & $25.0 \pm 7.4$ \\
Gleyic (G) & $19.7 \pm 2.7$ \\
Gleyic with oximorphic features (Gox) & $23.4 \pm 2.5$ \\
\hline
\end{tabular}

aRussian Soil Classification System (Šišov et al. 2004).

and Khalyatalbey rivers, Alluvial and Stratified soil orders develop. These soils consist of many soil horizons (layers) that have different soil properties.

\section{Soil physical-chemical properties}

The basic soil parameters for the studied soils are presented in Table 3. The $\mathrm{pH}$ values were predominantly strongly acidic within the soil profiles. Measured exchangeable acidity varied from 0.03 to $4.00 \mathrm{cmolP}^{+} \mathrm{kg}^{-1}$. The lowest values were found in the Histic topsoil horizons of the Histic Cryosol/ Peaty Eutrophic soil, underlain by permafrost. Hydrolytic acidity values ranged from 0.07 to $4.00 \mathrm{cmolP}^{+} \mathrm{kg}^{-1}$.

Organic carbon was highest in Histic and litter topsoil horizons (up to $33.95 \%$ ). The contents of nitrogen were also highest in the topsoil horizons. No elevated values of organic carbon or nitrogen were found in the transition horizons; however, the buried organogenic horizon (Erkuta River) showed even higher carbon content than the topsoil horizon. The $\mathrm{C}: \mathrm{N}$ ratios ranged between 29.94 and 87.04 in the topsoil horizons. Analysis of C:N mean values within the studied plots revealed that the soils of the Polar Urals site had the widest ratio, likely as a result of the site having a more gradual profile distribution within the illuvial profile. These soils were characterized by lower variability of $\mathrm{C}: \mathrm{N}$, while this parameter was relatively high $(>30)$ in topsoil horizons (mainly litter and raw-humus). In contrast, although there was a very wide $\mathrm{C}: \mathrm{N}$ ratio in the topsoil Histic horizon, Histic Spodic Cryosols/Peat Podzols underlain by permafrost were characterized by a more dramatic decrease in C:N within the soil profile. High C:N ratios observed at some sites are caused by a lack of oxygen in over-moistened conditions and, consequently, low soil organic matter decomposition. The wide $\mathrm{C}: \mathrm{N}$ ratio suggests a deficit of nitrogen, inhibited decomposition of plant remnants and accumulation of organic peat material. Lower values of $\mathrm{C}: \mathrm{N}$ ratio in lower horizons are explained by better aeration conditions and, thus, a higher decomposition rate. Many soil profiles within the study area demonstrated an unequal distribution of SOC, nitrogen content and different C:N ratios. This observation supports data reported previously for permafrost-affected soils in various sectors of the Arctic (Zubrzycki et al. 2013; Zubrzycki et al. 2014) and is the type of evidence needed to properly investigate soil carbon and nitrogen pools. The manifestation of cryoturbation and buried organic matter makes this particularly important and should be accurately assessed 

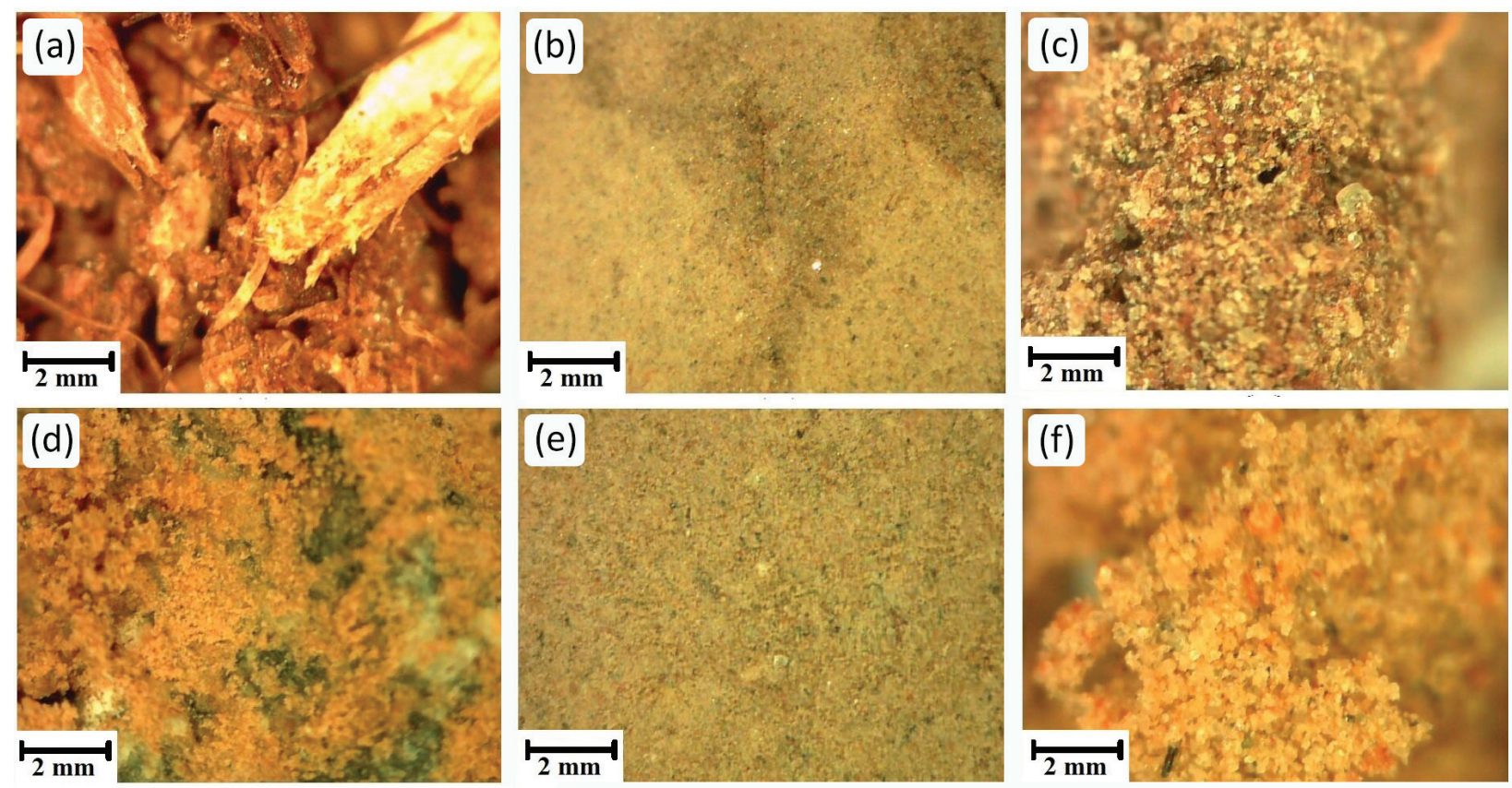

Fig. 3 Morphological features of selected horizons in the studied soils: (a) cryoconservation in a superficial layer of Histic Stagnic Cryosol/Peat Gleyzem underlain by permafrost (Khalyatalbey River); (b) organic matter in a cryogenic crack (Histic Stagnic Cryosol/Peat Gleyzem underlain by permafrost, Kerdamon-Shor Valley, the Polar Urals); (c) buried organic matter horizon (Histic Stagnic Cryosol/Peat Gleyzem underlain by permafrost, vicinity of Salekhard); (d) cryoturbation in a sorted circle (Turbic Cryosol/Typic Cryozem, Chyornaya Mountain); (e) stagnic horizon (Histic Stagnic Cryosol/Peat Gleyzem underlain by permafrost, Erkuta River); (f) accumulation of iron in the illuvial spodic horizon (Histic Spodic Cryosol/Peat Podzol underlain by permafrost, vicinity of Salekhard).

in the development of sampling approaches (Zubrzycki et al. 2013).

\section{Soil basal respiration}

Analysis of basal soil respiration data revealed several trends in its profile distribution (Fig. 4). The measured parameters of the microbiological activity of the soils indicate that in most of the studied soils, the highest basal respiration rate was in the upper horizon, especially in Histic horizons, corresponding to high microbial biomass (Fig. 4b). Moreover, in the underlying horizons, a decrease in the basal respiration was also observed. Turbic Cryosols/Typic Cryozem from the Erkuta River sites underlain by permafrost showed a complicated profile distribution of basal soil respiration (Fig. 4a), explained by cryogenic mass transfer and inclusion of organic matter from topsoil. The data on soil respiration are crucial for soil carbon turnover modelling to simulate greenhouse gas emissions and soil organic dynamics under conditions of a changing climate. Chemical properties of soil are not the only factors affecting soil respiration levels (Lubbe \& Smith 2012). Climatic conditions-temperature and soil moisture-are also important (Abakumov \& Mukhametova 2014).

Table 4 reveals the correlation of basal soil respiration with soil physical-chemical parameters rates was strongly positively correlated with carbon $(r=0.813, p<0.001)$ and nitrogen $(r=0.786, p<0.001)$ contents, and the $\mathrm{C}: \mathrm{N}$ ratio $(r=0.786, p<0.001)$. A moderate negative correlation was found between basal soil respiration and $\mathrm{pH}(r=-0.528$, $p=0.005)$. No significant correlations were found with both acidity forms. This confirms that upper horizons with increased organic carbon and nitrogen content are characterized by higher microbial activity. It has been demonstrated previously that profile distribution of basal soil respiration for permafrost-affected soils has a decreasing trend with depth (Abakumov \& Mukhametova 2014; Evgrafova \& Mukhortova 2015). We found that basal respiration decreased with depth and was strongly correlated with organic carbon content. The decomposability rate of soil organic matter in permafrost-affected soils is usually higher in the surface-active layer (Walz et al. 2017). At the same time, $\mathrm{CO}_{2}$ production in soil layers below this level does not significantly differ from those in permafrost. That is why environmental conditions in the seasonally 


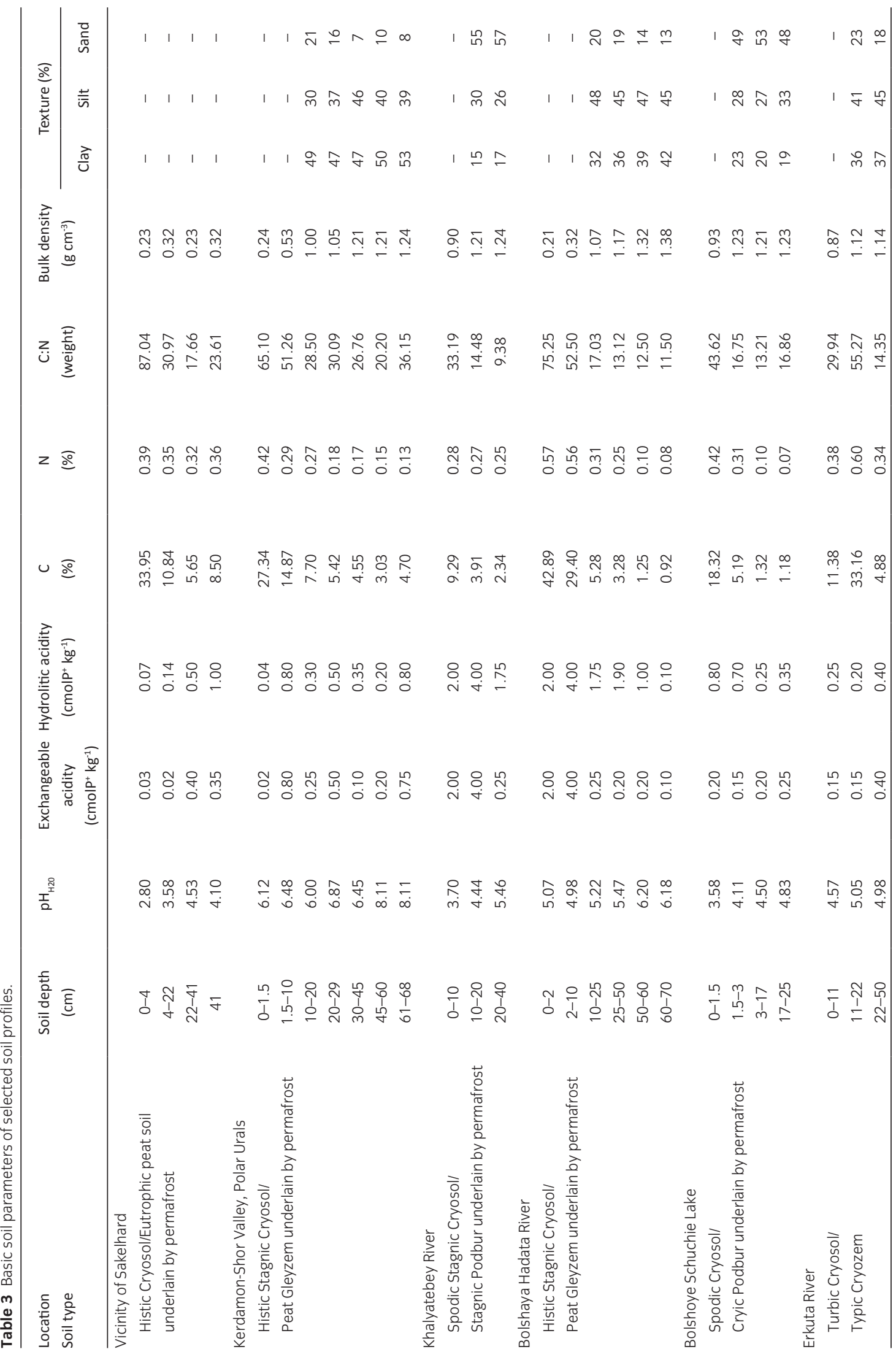


(a)
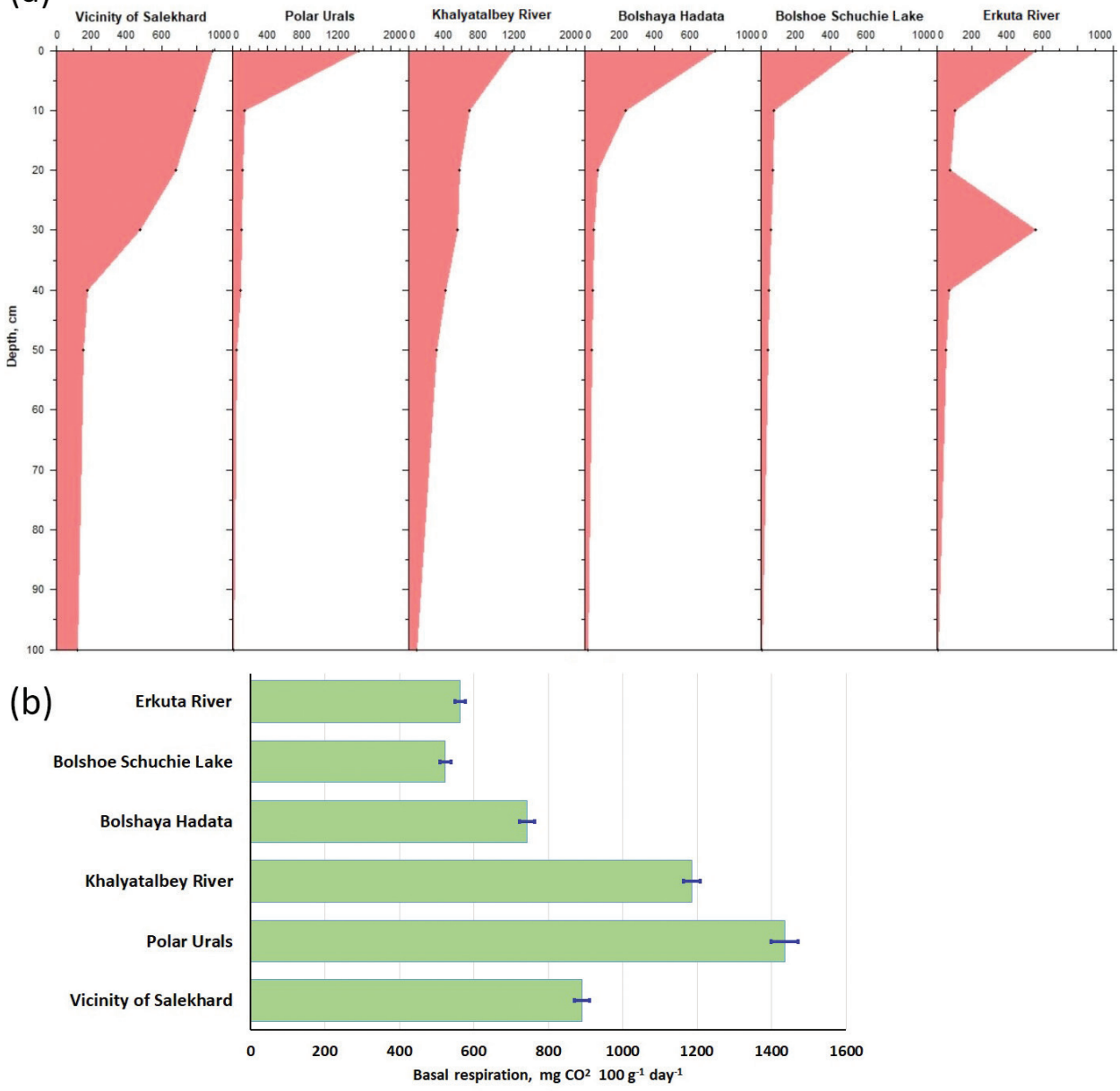

Fig. 4 Soil basal respiration ( $\mathrm{mg} \mathrm{CO}_{2} 100 \mathrm{~g}^{-1}$ day $^{-1}$ ) in studied soils: (a) profile distribution; (b) topsoil horizons (error bars represent standard error).

Table 4 Correlation of basal soil respiration with soil physical-chemical properties (according to Spearman's rank correlation coefficient).

\begin{tabular}{ccccccc}
\hline & $\mathrm{pH}$ & Exchangeable acidity & Hydrolitic acidity & Total organic carbon (\%) & $N(\%)$ & C:N \\
\hline \multirow{2}{*}{ Basal respiration } & -0.528 & 0.004 & -0.118 & 0.813 & 0.786 & 0.7 \\
& $p$ value 0.005 & 0.983 & 0.558 & $<0.001$ & $<0.001$ & $<0.001$ \\
\hline
\end{tabular}

thawed active layer and perennially frozen permafrost are markedly different and will probably respond differently to changes caused by warming (Gillespie et al. 2014).

\section{sOC pools}

Sampled soils in the Polar Urals were characterized by the highest mean SOC pools $\left(9.87 \pm 4.60 \mathrm{~kg} \mathrm{~m}^{-2}\right)$ in the 0-10 cm layer (Table 5) among the soils tested in this study, which is largely explained by the high organic carbon content in the topsoil of the Histic Stagnic Cryosol formed in the Kerdamon-Shor Valley.

SOC stocks showed pronounced differences from horizon to horizon at three sites-the vicinity of Salekhard, the Polar Urals and the Erkuta River-likely due to thicker Histic horizons and greater accumulation of organic matter in lower horizons of soils from these sites. The Khalytalbey River, Bolshaya Hadata River and Bolshoe Schuchie Lake sites showed lower variability of SOC stocks in the soil profile. Soils in these areas are generally 
Table $5 \mathrm{SOC}$ pools $\left(\mathrm{kg} \mathrm{m}^{-2}\right)$ in different reference soil layers of study sites.

\begin{tabular}{lccc}
\hline Site & SOC stock 0-10 cm (mean \pm SD $)$ & SOC stock 0-30 cm (mean \pm SD) & SOC stock 0-100 cm (mean \pm SD) \\
\hline Vicinity of Salekhard & $7.25 \pm 4.92$ & $9.88 \pm 3.83$ & $28.54 \pm 4.39$ \\
Polar Urals (Chyornaya Mountain, & $9.87 \pm 4.60$ & $14.65 \pm 3.74$ & $30.51 \pm 3.81$ \\
$\quad$ Kerdamon-Shor Valley) & $5.79 \pm 2.71$ & $14.23 \pm 3.68$ & $14.83 \pm 3.60$ \\
Khalyatalbey River & $5.81 \pm 3.19$ & $16.31 \pm 7.34$ & $19.14 \pm 5.53$ \\
Bolshaya Hadata River & $5.97 \pm 2.93$ & $9.15 \pm 2.32$ & $16.93 \pm 2.18$ \\
Bolshoye Schuchie Lake & $7.02 \pm 5.48$ & $28.90 \pm 15.78$ & $33.97 \pm 13.68$ \\
Erkuta River &
\end{tabular}

thinner and include a lot of gravel, which limits the accumulation of organic matter.

The mean SOC stock for the study area was $7.85 \pm$ $2.24 \mathrm{~kg} \mathrm{~m}^{-2}$ (0-10 cm layer), $14.97 \pm 5.53 \mathrm{~kg} \mathrm{~m}^{-2}(0-30 \mathrm{~cm})$ and $23.99 \pm 8.00 \mathrm{~kg} \mathrm{~m}^{-2}(0-100 \mathrm{~cm})$. It has been previously discussed by Zubrzycki et al. (2014) that SOC storage within the top metre of permafrost-affected soils in the Arctic ranges significantly (from 4.0 to $71.3 \mathrm{~kg} \mathrm{C} \mathrm{m}^{-2}$ ). They proposed that this is due to the high diversity of studied environments.

Only a few comprehensive investigations of SOC pools in Arctic soils have been conducted previously. Post et al. (1982) reported $21.8 \mathrm{~kg} \mathrm{~m}^{-2}$ as the SOC stock in tundra soils worldwide. Matsuura \& Yefremov (1995) measured the SOC stock between $11 \mathrm{~kg} \mathrm{~m}^{-2}$ and $20 \mathrm{~kg}$ $\mathrm{m}^{-2}$ in the permafrost-affected soils of Russia, while Kolchugina et al. (1995) obtained a value of $21.4 \mathrm{~kg} \mathrm{~m}^{-2}$. Ping et al. (1997) estimated the SOC stocks of the Alaskan tundra to range between 31.4 and $69.2 \mathrm{~kg} \mathrm{~m}^{-2}$. For the eastern European Russian tundra, an SOC stock value of $17.8 \mathrm{~kg} \mathrm{~m}^{-2}$ was reported by Čestnyh et al. (1999), who estimated SOC stocks of tundra soils to be $10.10 \pm 3.21 \mathrm{~kg} \mathrm{~m}^{-2}$ in the Kola Peninsula (mean \pm $\mathrm{SD}), 16.80 \pm 6.79 \mathrm{~kg} \mathrm{~m}^{-2}$ in the eastern European Russian tundra, $10.20 \pm 3.10 \mathrm{~kg} \mathrm{~m}^{-2}$ in the Polar Urals, 1.84 $\pm 0.15 \mathrm{~kg} \mathrm{~m}^{-2}$ on the islands of the Barents and Kara seas, $7.50 \pm 1.21 \mathrm{~kg} \mathrm{~m}^{-2}$ in western Siberia, $8.79 \pm 2.31$ $\mathrm{kg} \mathrm{m}^{-2}$ in central Siberia, $10.37 \pm 2.82 \mathrm{~kg} \mathrm{~m}^{-2}$ in Yakutia, $7.51 \pm 1.20 \mathrm{~kg} \mathrm{~m}^{-2}$ on islands in the Laptev, Eastern Siberian and Chukchi seas and $9.58 \pm 3.66 \mathrm{~kg} \mathrm{~m}^{-2}$ in the Chukotka-Anadyr province. Čestnyh et al. (1999) also reported a value of $10.30 \mathrm{~kg} \mathrm{~m}^{-2}$ for the SOC stock in all Russian tundra soils. More recent publications provide higher values of SOC stocks in tundra soils. Hugelius $\delta$ Kuhry (2009) reported $38.7 \mathrm{~kg} \mathrm{~m}^{-2}$ for the north-eastern European Russian tundra soils. In North American Arctic lowlands, Ping et al. (2008) measured SOC stocks of $25.9 \mathrm{~kg} \mathrm{~m}^{-2}$. Tarnocai et al. (2009) reported values of $32.2 \mathrm{~kg} \mathrm{~m}^{-2}$ and $22.6 \mathrm{~kg} \mathrm{~m}^{-2}$ for organic carbon stocks in the Turbel and Orthel soils of the circumpolar permafrost region, respectively. Stolbovoi (2002) estimated the stock in Russian tundra soils to be $16.6 \mathrm{~kg} \mathrm{~m}^{-2}$. Gundelwein et al. (2007) found that the SOC stock in tundra soils of the Taymyr Peninsula was $30.7 \mathrm{~kg} \mathrm{~m}^{-2}$. Hugelius et al. (2010) estimated the SOC stocks of permafrost-affected soils to be up to $33.8 \mathrm{~kg} \mathrm{~m}^{-2}$ in the central Canadian Arctic surrounding Tulemalu Lake. Zubrzycki et al. found stocks of $23.7 \pm 5.4 \mathrm{~kg} \mathrm{~m}^{-2}$ (Zubrzycki et al. 2013) and $29.5 \pm 10.5 \mathrm{~kg} \mathrm{~m}^{-2}$ (Zubrzycki et al. 2014) for the river terraces terrace in Lena River Delta. Siewert et al. (2016) found stocks of $27.9 \pm 2.9 \mathrm{~kg} \mathrm{~m}^{-2}$ for a lowland tundra environment in Kytalyk, north-eastern Siberia.

Estimates of SOC stock in the soils of the Polar Urals reported in this work were higher-14.65 $\pm 3.74 \mathrm{~kg} \mathrm{~m}^{-2}-$ than those calculated by Čestnyh et al. (1999)-10.20 \pm $3.10 \mathrm{~kg} \mathrm{~m}^{-2}$. Unfortunately, these values cannot be compared confidently on the account of differences in sampling and data analyses.

There are also sizeable uncertainties in SOC pools estimations due to the great variation in the thickness of the active layer in different Arctic sub-regions. A detailed study examined the interactions between relief, soil vegetation cover and permafrost microrelief at micro- and mesoscales (Gubin \& Lupachev 2008). To accurately evaluate soil depositary functions (i.e., to calculate SOC pools) in the Arctic, the permafrost table microrelief should be taken into account, since it determines the lateral redistribution of energy and matter within the cryogenic ecosystems. Gubin \& Lupachev (2008) identify soil and vegetation cover, lithological composition, texture class, duration of thawing season, redistribution of matter and energy in the superficial layer, anthropogenic influence and cryoconservation of soil contaminants as the main factors affecting the structure and dynamics of active layer microrelief (Gubin \& Lupachev 2008). It has been also shown that changes in surface relief can affect the accumulation of organic matter in permafrost landscapes (Lupachev et al. 2016). Organogenic horizons are almost continuously represented at the southern limits of the Arctic (excluding 
cases of sorted circles and disturbance of the soil surface caused by thermokarst and solifluction), but their thickness ranges markedly, from $0 \mathrm{~cm}$ in spots with no vegetation, $2-5 \mathrm{~cm}$ in the centres of vegetation-covered polygons to $20-40 \mathrm{~cm}$ in inter-polygonal cracks.

\section{Fractional composition of humus}

Measurements of carbon in humic and fulvic acids and their ratio in topsoils are summarized in Table 6. The widest Cha:Cfa ratio was observed for Stagnic Spodic Cryosol/Raw-humus Gleyic Podbur underlain by permafrost (Khalyatalbey River site) on clayey parent material at the forest-tundra (dominated by Larix sibirica, Betula nana, Empetrum nigrum), which demonstrates the highest rate of humification conditions of litter influx to the soil. The litter is enriched with lignin compounds in the forest-tundra. This confirms that the origin of the organic matter, together with its composition, significantly affects the C:N ratio, so this parameter could be used for determining organic matter degradation-mineralizing risks. This agrees with previously published data and supports the idea that the possible risks of organic matter degradation under the observed climate change are high for stabilized organic matter in the Arctic (Abakumov \& Mukhametova 2014). The lowest Cha:Cfa ratios were observed in soils with a thick Histic horizon, which is connected to conservation and a slow rate of plant residue humification. The data demonstrate different rates of organic remnant humification under various lithologic-geochemical conditions.
Most of the soils are characterized by a fulvic type of humus. Notably, soils of the Polar Urals and its foothills are characterized by wider Cha:Cfa ratios compared to those from flat tundra sites, which can be linked to a higher percentage of shrubs in the vegetation cover and the influence of lithological factors on the humification process.

The Cha:Cfa ratio directly characterizes the stability of organic matter in permafrost-affected soils - the wider the ratio, the more stable the organic matter-so organic matter in forest-tundra soils is usually the most stable among studied soils. The lowest value of the Cha:Cfa ratio found in the Histic horizons demonstrates the importance of studying soil organic pools, especially for peat tundra sites, which are the main sources of unstable SOC (Hugelius \& Kuhry 2009).

There are still many gaps and uncertainties in understanding the mechanisms of humification, which are shaped by a few different factors of terrestrial humification. The ratio of Cha:Cfa serves as a quantitative characteristic of humus, differs in soils of various zones and depends mainly on bioclimatic conditions and lithological-geochemical characteristics. Usually, the humus of polar soils is characterized by a predominance of fulvic acids (Evgrafova \& Mukhortova 2015). The role of humic acids increases towards the south in boreal and sub-boreal zones (from predominance of humic-fulvic and fulvic-humic types to a humic one). Precursors of humification are oligomers and monomers, which are strongly affected by vegetation type and species composition. The observed predominance of Cfa (and fulvic type

Table 6 Cha:Cfa analysis in the topsoil horizon of selected soils of studied key sites.

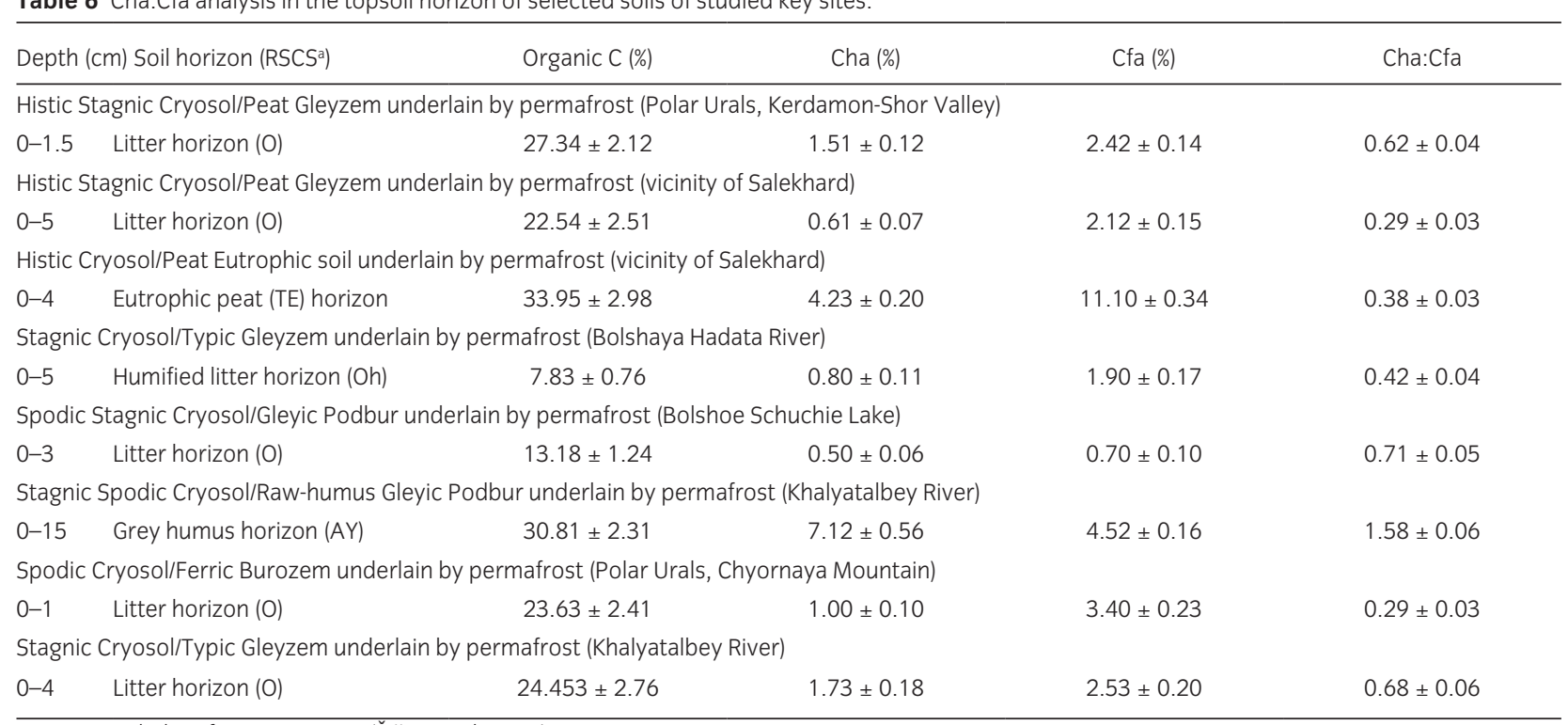

aRussian Soil Classification System (Šišov et al. 2004). 
of humus), together with the predominance of low-molecular fragments in the fulvic acid fraction, indicates high mineralization risks in the humus systems of polar soils under the conditions of predicted Arctic warming.

\section{Microbiome composition and its relationship with soil properties}

The soil cover of Yamal has been investigated in only a few studies, devoted mainly to natural soils (Alekseev et al. 2016; Alekseev, Dinkelaker et al. 2017; Matyshak et al. 2017; Alekseev et al. 2019). Mainly pedological and geophysical research has been conducted, and microbiological studies in this region have been limited by the application of conventional microbiological methods (Kitrsideli et al. 2014; Vlasov et al. 2014). In this study, we used a high-throughput next-generation sequencing approach. Generally, Arctic bacterial communities seem to be dominated by different taxa than other biomes, likely reflecting the impact of polar environmental conditions on microbial communities (Malard et al. 2019). Tundra soils are generally characterized as poorly enriched by organic matter, over-saturated and poorly aerated. These conditions result in relatively low microbial community levels.

Taxonomic analysis of the soil microbiomes revealed 48 bacterial and archaeal phyla, including Proteobacteria (27\% on average), Actinobacteria $(20 \%)$, Acidobacteria (13\%), Chroloflexi (12\%), Gemmatimonadetes (7\%), Verrucomicrobia $(7 \%)$, Planctomycetes $(6 \%)$, Bacteroidetes $(2 \%), \operatorname{AD} 3(3 \%)$ and Nitrospirae $(3 \%)$, together constituting more than $95 \%$ of the sequences in the amplicon libraries. Archaea were represented by the phyla Crenarchaeota $(0.2 \%)$, Euryarchaeota $(0.1 \%)$ and some Parvarchaeota. The abundance of the oligotrophic phylum Acidobacteria, which is found in acidic Histic Cryosol topsoils, is accounted for by the warm and humid conditions of the southern Yamal Peninsula, along with the presence of large portion of organic remnants in the topsoil layers.

Numerous natural and anthropogenic factors influence soil fertility and microbial communities, and these factors must be considered when interpreting the soil microbiome parameters (Yan et al. 2015; Li et al. 2017). In this work, we discuss only some of these factors. It should be noted, however, that climatic parameters (such as temperature and precipitation), which can significantly affect the soil microbial community on a larger scale, probably did not have much of an impact on microbial diversity from site to site within the study area, since the soil samples were collected from the same bioclimatic region and were therefore exposed to similar weather conditions.

Several indices for species richness and evenness were calculated to evaluate the alpha diversity of the vegetation microbiomes (Table 7). The number of OTUs was higher in Histic Stagnic Cryosol/Peat Gleyzem underlain by permafrost (Kerdamon-Shor Valley, the Polar Urals) and Histic Cryosol/Eutrophic peat soil underlain by permafrost (vicinity of Salekhard), probably as a result of the less acidic $\mathrm{pH}$ (acid-neutral) in topsoil horizons at these sites than at the other sites (which were exclusively acidic). These results are consistent with the results of basal respiration analyses, in which the higher values were found in Histic horizons. Previous studies have shown that both alkaline and acidic soils should be generally considered as harsh environments for microbial communities, and that microbial communities adapt to such conditions in a variety of ways (Clark \& Baligar 2000; Fierer \& Jackson 2006; Rousk et al. 2010). Acid-neutral soils are optimal for microbial communities, reflected by our findings of microbial community composition and $\mathrm{pH}$ ranges in the soils studied.

Table 7 presents the values of the following alpha-biodiversity parameters: OTUs, Chaol and Shannon indices. Alpha diversity was significantly lower in acidic topsoil

Table 7 Alpha-diversity parameters of the topsoil materials.

\begin{tabular}{lcccc}
\hline Sample type & OTUs & Phylogenetic diversity & Chao1 & Shannon index \\
\hline $\begin{array}{l}\text { Histic Cryosol/Eutrophic peat soil underlain by } \\
\text { permafrost (vicinity of Salekhard) }\end{array}$ & $1678.5 \pm 49.0$ & $15.19 \pm 3.54$ & $289.1 \pm 191.4$ & $7.0 \pm 0.1$ \\
$\begin{array}{l}\text { Spodic Cryosol/Cryic Podbur (Bolshoe Schuchie Lake) } \\
\text { Stagnic Cryosol/Gleyic Podbur underlain by permafrost } \\
\quad \text { Khalyatelbey River) }\end{array}$ & $1420.5 \pm 67.2$ & $24.33 \pm 2.34$ & $223.6 \pm 166.8$. & $7.9 \pm 0.2$ \\
$\begin{array}{l}\text { Histic Stagnic Cryosol/Peat Gleyzem underlain by } \\
\quad \text { permafrost (Kerdamon-Shor Valley, Polar Urals) }\end{array}$ & $1565.7 \pm 77.0$ & $22.15 \pm 2.01$ & $278.5 \pm 144.0$ & $7.2 \pm 0.3$ \\
$\begin{array}{l}\text { Histic Stagnic Cryosol/Peat Gleyzem underlain by } \\
\text { permafrost (Bolshaya Hadata River) }\end{array}$ & $1457.7 \pm 67.9$ & $15.67 \pm 2.03$ & $245.6 \pm 123.4$ & $7.9 \pm 0.2$ \\
\begin{tabular}{l} 
Turbic Cryosol/Typic Cryozem (Erkuta River) \\
\hline
\end{tabular} & $1568.0 \pm 43.5$ & $13.45 \pm 3.45$ & $256.7 \pm 125.6$ & $7.4 \pm 0.1$ \\
\hline
\end{tabular}


samples than in acid-neutral soils. The number of OTUs ranged from $1420.5 \pm 67.2$ to $1678.5 \pm 49.0$. The highest species diversity (Chaol index) was found in topsoils surrounding the Salekhard and Khalyatalbey rivers. The Shannon index varied from 7.0 to 7.9 overall, and the highest values were found in topsoils from the Histic Stagnic Cryosol Kerdamon-Shor Valley (Histic Stagnic Cryosol) and Bolshoe Schuchie Lake (Spodic Cryosol), which is explained by less acidic $\mathrm{pH}$ values (slightly acidic to acid-neutral). The lowest values of the Shannon index were in topsoils with relatively low levels of nitrogen accumulation. It seems likely that the increased productivity in vascular plants-an obvious result of recent warming at the Bolshoe Schuchie Lake and Khalyatabley River sites-has caused shifts in the soil bacterial community over time. This probably explains the higher levels of phylogenetic diversity that we found in the soils at these sites, which is consistent with earlier research on tundra soils (Shaver et al. 2001).

The Spearman's rank correlation coefficient was used to estimate a correlation between the alpha-diversity of the studied soils with nutritional factors: $\mathrm{pH}, \mathrm{C}$ and $\mathrm{N}$ concentrations, and $\mathrm{C}: \mathrm{N}$ ratio (Table 8 ). The $\mathrm{pH}$ values were found to be negatively correlated with OTU values $(r=-0.333)$, although that correlation was not statistically significant. The Chaol index was found to be strongly negatively correlated with $\mathrm{pH}(r=-0.810$, $p<0.001)$, and $\mathrm{pH}$ demonstrated a strong positive correlation $(r=0.838, p<0.001)$ with the Shannon index and a moderate positive correlation with the phylogenetic diversity index $(r=0.697, p=0.002)$. Carbon concentration was moderately correlated with OTU values $(r=0.437)$, but $P$ values were not significant. Nitrogen concentrations showed a strong positive correlation with the Shannon diversity index $(r=0.707, p=0.001)$ and moderately negative correlation with the Chaol richness estimator $(r=-0.698, p=0.001)$. Our data on significant correlations between soil microbial community indices and soil physico-chemical parameters ( $\mathrm{pH}$, nitrogen concentration and availability) are consistent with those previously reported for different Arctic regions (Lauber et al. 2009; Koyama et al. 2014).

To understand the correlation between soil physico-chemical parameters and alpha-diversity indices of microbial communities as well as OTUs, the PCA was used (Fig. 5). Axes 1 and 2 represent $52.37 \%$ and $35.84 \%$ of the variation in the data, respectively. The largest factor loadings for the first component were organic Shannon index $(24.2 \%)$, Chaol $(23.5 \%)$, total $\mathrm{N}(19.9 \%)$ and $\mathrm{pH}(17.4 \%)$. The largest factor loadings for the second component were the C:N ratio $(26.9 \%)$, phylogenetic diversity $(24.9 \%)$ and carbon content $(21.2 \%)$. The analysed parameters can be divided into three groups: (1) nitrogen content, carbon content and C:N ratio; (2) Shannon index, pH and phylogenetic diversity index; (3) species richness index Chaol. In addition, group I contains topsoil from the Polar Urals site, and group 2 contains topsoil from the Bolshoe Schuchie Lake site. Parameters from both groups I and II are negatively correlated with topsoils from the rest of the investigated sites.

Previous studies have shown that soil $\mathrm{pH}$ and nitrogen content are the most important contributors to the variation in soil microbial communities and are considered good predictors of bacterial community composition (Rousk et al. 2010; Koyama et al. 2014; Li et al. 2017). On the account of the narrow $\mathrm{pH}$ range that is optimal for bacterial growth, a soil's $\mathrm{pH}$ is understood to be the main environmental factor, determining microbial community composition not only across biomes but also for individual soil types (Lauber et al. 2009; Rousk et al. 2010; Alekseev et al. 2020). However, in some cases (Actinobacteria and Bacteriodetes), microbial community composition might also be significantly correlated with other soil environmental variables, such as carbon content and availability (Alekseev et al. 2020; Koyama et al. 2014). At the same time, the diversity of the soil bacterial community

Table $\mathbf{8}$ Correlation of the alpha-diversity parameters with soil physical-chemical properties (Spearman's rank correlation coefficient).

\begin{tabular}{|c|c|c|c|c|c|c|c|c|}
\hline & $\begin{array}{c}\text { OTUs } \\
(n=18)\end{array}$ & $\begin{array}{c}\text { Shannon index } \\
(n=18)\end{array}$ & $\begin{array}{l}\text { Chao1 } \\
(n=18)\end{array}$ & $\begin{array}{c}\text { Phylogenetic } \\
\text { diversity }(n=18)\end{array}$ & $\begin{array}{c}\mathrm{pH} \\
(n=18)\end{array}$ & $\begin{array}{c}C \\
(\% ; n=18)\end{array}$ & $\begin{array}{c}\mathrm{N} \\
(\% ; n=18)\end{array}$ & $\begin{array}{c}\text { C:N } \\
(n=18)\end{array}$ \\
\hline \multicolumn{9}{|c|}{ Shannon index } \\
\hline OTUs & & -0.441 & 0.6 & & & & & \\
\hline PD & -0.429 & 0.324 & -0.314 & & & & & \\
\hline $\mathrm{pH}$ & -0.333 & $0.838^{c}$ & $-0.810^{c}$ & $0.697^{b}$ & & & & \\
\hline $\mathrm{C}(\%)$ & 0.437 & 0.331 & -0.300 & -0.304 & 0.143 & & & \\
\hline $\mathrm{N}(\%)$ & -0.006 & $0.707^{c}$ & $-0.698^{c}$ & -0.229 & 0.377 & $0.812^{\mathrm{a}}$ & & \\
\hline $\mathrm{C}: \mathrm{N}$ & 0.389 & 0.006 & -0.044 & -0.321 & -0.143 & $0.886^{a}$ & 0.580 & \\
\hline
\end{tabular}

${ }^{a} p<0.05 .{ }^{b} p<0.01 .{ }^{c} p<0.001$. 


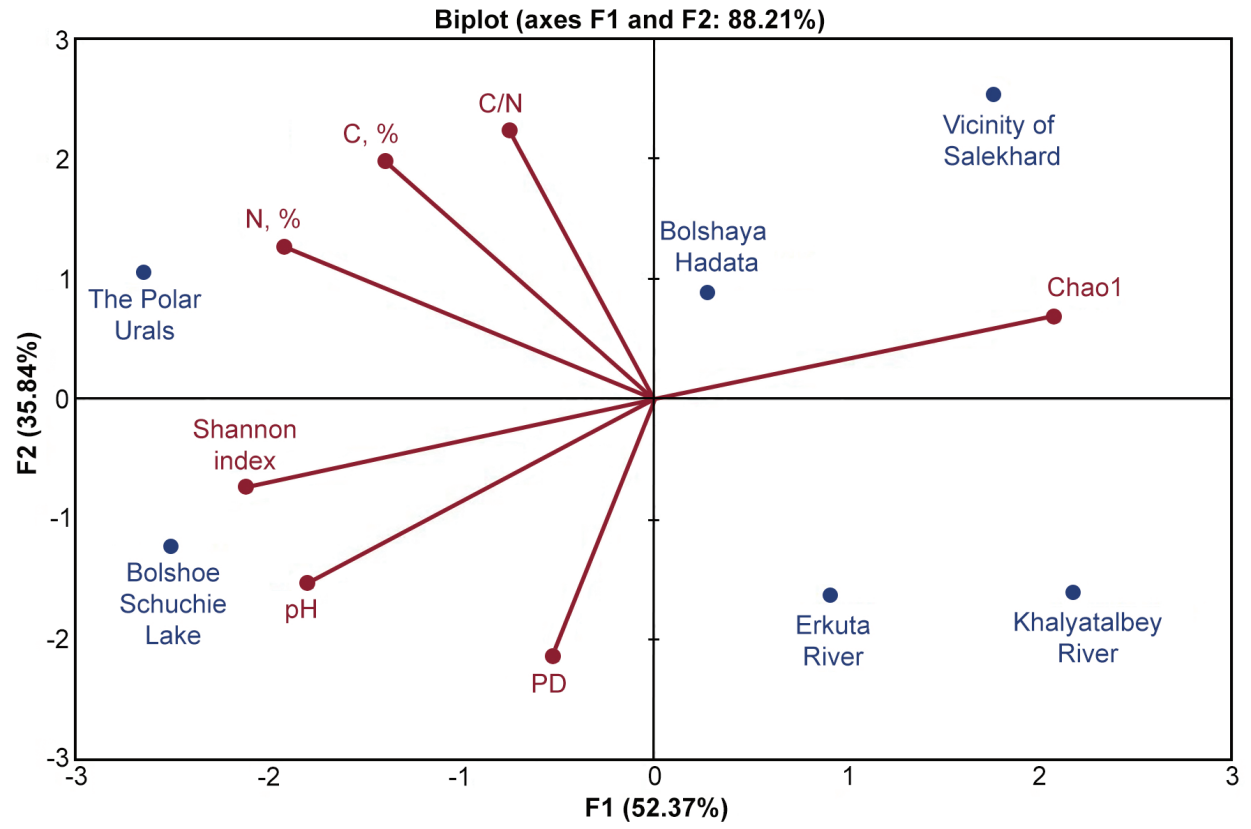

Fig. 5 PCA based on soil physico-chemical characteristics as variables. The applied rotation method is varimax.

has a substantial effect on nutrient (including nitrogen) cycling. Alteration of soil microbial community composition caused by nitrogen content and availability is likely to affect soil organic matter cycling significantly.

Arctic warming will very likely significantly influence the functional diversity of microbial communities in permafrost soils. It has been reported that increasing temperatures at high latitudes will stimulate microbial activity, and the massive amount of carbon stored in permafrost will be decomposed and released into the atmosphere, accelerating climate change (Zimov et al. 2006; Hugelius \& Kuhry 2009). Although soil microbial communities have been the subject of detailed study in temperate environments, little information has been published for permafrost environments. Of particular interest in the comprehensive study of microbial diversity and its effects on the functioning and stability of the Arctic and sub-Arctic ecosystems are the carbon dynamics controlled by the microbiome and the impact of changing environmental conditions on microbiome functioning in the Arctic, which remain poorly understood.

\section{Conclusions}

The mean SOC stock for the study area was $7.85 \pm$ $2.24 \mathrm{~kg} \mathrm{~m}^{-2}$ (for the $0-10 \mathrm{~cm}$ layer), $14.97 \pm 5.53 \mathrm{~kg}$ $\mathrm{m}^{-2}(0-30 \mathrm{~cm})$ and $23.99 \pm 8.00 \mathrm{~kg} \mathrm{~m}^{-2}(0-100 \mathrm{~cm})$. These findings, from an area about which little has been published regarding soil carbon pools, are generally consistent with, and add to, previous studies of SOC storage in permafrost-affected Arctic soils. Some discrepancies also emerged between our results and those from other studies, which are explained by differences in sampling and calculating approaches. More detailed fieldwork is needed to precisely characterize site-scale SOC pools (not only SOC heterogeneity on the scale of the tundra biome). Moreover, a unified soil classification, or at least a consistent approach to soil sampling that considers specific soil horizons, is needed for investigations of SOC stocks so that results can be fruitfully compared.

The observed predominance of the fulvic type of humus, together with the predominance of low-molecular fragments in the fulvic acid fraction, demonstrates high mineralization risks in humus in permafrost soils under predicted Arctic warming.

Analysis of microbiome composition showed that less acidic samples had higher microbial alpha-diversity. Taxonomic analysis of soil microbiomes revealed 48 bacterial and archaeal phyla, among which Proteobacteria $(27 \%$ on average) and Actinobacteria (20\%) were predominant. The $\mathrm{pH}$ range and nitrogen accumulation levels were found to be the main factors determining microbial community diversity and composition in the studied soils. The $\mathrm{pH}$ was found to be strongly positively correlated with the Shannon index and moderately positively correlated with the phylogenetic diversity index. 
This work contributes to the estimation of the global organic carbon budget and the data set on soil characteristics of permafrost-affected soils of the Arctic. There should be more comprehensive investigations of the properties and dynamics of landscapes in conditions influenced by permafrost and they should be spatially more distributed.

\section{Details of data deposit}

Sequences can be requested from the corresponding author.

\section{Acknowledgements}

The authors thank the anonymous reviewers for critically reading the manuscript and suggesting substantial improvements. The authors also acknowledge the laboratory staff at the Department of Applied Ecology, Saint Petersburg State University, for their assistance with soil chemical analyses.

\section{Funding}

This study was supported by the Russian Foundation for basic research, grant nos. 19-416-890002 (Microbiome of Abandoned Agricultural Soils of Yamal-Nenets Autonomous Region: Diversity, Properties and Dynamics) and 19-05-50107 (The Role of Microparticles of Organic Matter in Degradation of Glacial Cover in Polar Regions of Earth and Formation of Soil-like Bodies), and a grant from Saint Petersburg State University (Urbanized Ecosystems of the Russian Arctic: Dynamics, State and Sustainable Development).

\section{Disclosure statement}

The authors report no conflict of interest.

\section{References}

Abakumov E. \& Mukhametova N. 2014. Microbial biomass and basal respiration of selected Sub-Antarctic and Antarctic soils in the areas of some Russian polar stations. Solid Earth 5, 705-712, doi: 10.5194/se-5-705-2014.

Alekseev I. \& Abakumov E. 2018. Permafrost-affected former agricultural soils of the Salekhard city (central part of Yamal region). Czech Polar Reports 8, 119-131, doi: 10.5817/ CPR2018-1-9.

Alekseev I., Abakumov E., Shamilishvili G. \& Lodygin E. 2016. Soderzhanie tyazhelyh metallov i uglevodorodov $\mathrm{v}$ počvakh naselennyh punktov Yamalo-Neneckogo avtonomnogo okruga. (Heavy metals and hydrocarbons content in soils of settlements of the Yamal-Nenets autonomous region.) Gigiyena i Sanitariya 9, 818-821.

Alekseev I., Dinkelaker N., Oripova A., Sem'ina G., Morozova A. \& Abakumov E. 2017. Ocenka ekotoksikologičeskogo sostojanija počhv Polyarnogo Urala i yuzhnogo Yamala. (Assessment of ecotoxicological state of soils of the Polar Ural and southern Yamal.) Gigiyena $i$ sanitariya 10, 941-945.

Alekseev I., Kostecki J. \& Abakumov E. 2017. Vertical electrical resistivity sounding (VERS) of tundra and forest tundra soils of Yamal region. International Agrophysics 31, 1-8, doi: 10.1515/intag-2016-0037.

Alekseev I., Shamilishvilly G. \& Abakumov E. 2019. Content of trace elements in selected permafrost-affected soils of Yamal region with different functional load. Polarforschung 88, 125-133, doi: 10.2312/polarforschung.88.2.125.

Alekseev I., Zverev A. \& Abakumov E. 2020. Microbial communities in permafrost soils of Larsemann Hills, eastern Antarctica: environmental controls and effect of human impact. Microorganisms 8, article no. 1202, doi: 10.3390/ microorganisms8081202.

Aronesty E. 2013. Comparison of sequencing utility programs. The Open Bioinformatics Journal 7, 1-8, doi: 10.2174 /1875036201307010001.

Bailey V., Bolton H. \& Smith J. 2008. Substrate-induced respiration and selective inhibition as measures of microbial biomass in soils. In M. Carter \& E. Gregorich (eds.): Soil sampling and methods of analysis. Pp. 515-527. Boca Raton, FL: CRC Press.

Bates S.T., Berg-Lyons D., Caporaso J.G., Walters W.A., Knight R. \& Fierer N. 2010. Examining the global distribution of dominant archaeal populations in soil. ISME Journal 5, 908-917, doi: 10.1038/ismej.2010.171.

Bolger A.M., Lohse M. \& Usadel B. 2014. Trimmomatic, a flexible trimmer for illumina sequence data. Bioinformatics 30, 2114-2120, doi: 10.1093/bioinformatics/btul70.

Caporaso J.G., Kuczynski J., Stombaugh J., Bittinger K., Bushman F.D., Costello E.K., Fierer N., Pena A.G., Goodrich J.K., Gordon J.I., Huttley G.A., Kelley S., Knights D., Koenig J., Ley R., Lozupone C., McDonald D., Muegge B., Pirrung M., Reeder J., Sevinsky J., Turnbaugh P., Walters W., Wildmann J., Yatsunenko T., Zaneveld J. \& Knight R. 2010. QIIME allows analysis of high-throughput community sequencing data. Nature Methods 7, 335-336, doi: 10.1038/nmeth.f.303.

Čestnyh O.V., Zamolodčikov D.G. \& Karelin D.V. 1999. Zapasy organičeskogo ugleroda $\mathrm{v}$ počvakh tundrovyh i lesotundrovyh ekosistem Rossii. (Organic matter reserves in the soils of tundra and forest-tundra ecosystems of Russia.) Ecologia 6, 426-432.

Clark R.B. \& Baligar V.C. 2000. Acidic and alkaline soil constraints on plant mineral nutrition. In R.E. Wilkinson (ed.): Plant-environment interactions. Pp. 133-177. New York: Marcel Dekker Inc.

DeSantis T.Z., Hugenholts P., Larsen N., Rojas M., Brodie E.L., Keller K., Dalevi D., Hu P. \& Andersen G.L. 2006. Greengenes, a chimera-checked 16S rRNA gene database 
and workbench compatible with ARB. Applied and Environmental Microbiology 72, 5069-5072, doi: 10.1128/ AEM.03006-05.

Dobrinskij L.N. 1995. Priroda Jamala. (Nature of Yamal.) Ekaterinburg: Nauka.

Evgrafova S. \& Mukhortova L. 2015. Linking microbial community features and biodegradability of organic matter in Siberian permafrost affected soils. Ecology $\theta$ Safety 9, 207-215.

FAO (Food and Agriculture Organization) 2015. World Reference Base for Soil Resources 2014. International soil classification system for naming soils and creating legends for soil maps. Update 2015. World Soil Resources Reports 106. Rome: Food and Agriculture Organization.

Fierer N. \& Jackson R.B. 2006. The diversity and biogeography of soil bacterial communities. Proceedings of the National Academy of Sciences of the United States of America 103, 626-631, doi: 10.1073/pnas.0507535103.

Forbes B.C. \& Kumpula T. 2009. The ecological role and geography of reindeer (Rangifer tarandus) in northern Eurasia. Geographical Compass 3, 1356-1380, doi: 10.1111/ j.1749-8198.2009.00250.x.

Freeman C., Evans C.D., Monteith D.T., Reynolds B. \& Fenner N. 2001. Export of organic carbon from peat soils. Nature 412, 785-785, doi: 10.1038/35090628.

Gillespie A.W., Sanei H., Diochon A., Ellert B.H., Regier T.Z., Chevrier D., Dynes J.J., Tarnocai C. \& Gregorich E.G. 2014. Perennially and annually frozen soil carbon differ in their susceptibility to decomposition: analysis of Subarctic earth hummocks by bioassay, XANES and pyrolysis. Soil Biology and Biochemistry 68, 106-116, doi: 10.1016/j. soilbio.2013.09.021.

Goryačkin S.V. 2014. Počvenny pokrov Severa (struktura, genezis, ekologija, evoljucija). (Soil cover of the north [patterns, genesis, ecology, evolution].) Moscow: GEOS.

Gubin S.V. \& Lupachev A.V. 2008. Soil formation and the underlying permafrost. Eurasian Soil Science 41, 574-585, doi: 10.1134/S1064229308060021.

Gundelwein A., Müller-Lupp T., Sommerkorn M., Haupt E.T., Pfeiffer E.M. \& Wiechmann H. 2007. Carbon in tundra soils in the Lake Labaz region of Arctic Siberia. Eurasian Journal of Soil Science 58, 1164-1174, doi: 10.1111/j.1365-2389.2007.00908.x.

Hao X., Ball B., Culley J., Carter M. \& Parkin G. 2008. Soil density and porosity. In M. Carter $\&$ E. Gregorich (eds.): Soil sampling and methods of analysis. Pp. 743-761. Boca Raton, FL: CRC Press.

Hugelius G. \& Kuhry P. 2009. Landscape partitioning and environmental gradient analyses of soil organic carbon in a permafrost environment. Global Biogeochemical Cycles 23, GB3006, doi: 10.1029/2008GB003419.

Hugelius G., Kuhry P., Tarnocai C. \& Virtanen T. 2010. Soil organic carbon pools in a periglacial landscape: a case study from the central Canadian Arctic. Permafrost and Periglacial Processes 21, 16-29, doi: 10.1002/ppp.677.

Hugelius G., Strauss J., Zubrzycki S., Harden J.W., Schuur E.A., Ping C.-L., Schirrmeister L., Grosse G., Michaelson G.J., Koven C.D., O’Donnell J.A., Elberling B., Mishra U., Camill P., Yu Z., Palmtag J. \& Kuhry P. 2014. Estimated stocks of circumpolar permafrost carbon with quantified uncertainty ranges and identified data gaps. Biogeosciences 11, 6573-6593, doi: 10.5194/bg-11-6573-2014.

Kačinskij N.A. 1970. Fizika počv. (Soil physics.) Moscow: Vysšhaja škola.

Kaiser C., Fuchslueger L., Koranda M., Gorfer M., Stange C.F., Kitzler B., Rasche F., Strauss J., Sessitsch A., Zechmeister-Boltenstern S. \& Richter A. 2011. Plants control the seasonal dynamics of microbial $\mathrm{N}$ cycling in a beech forest soil by belowground C allocation. Ecology 92, 1036-1051, doi: 10.1890/10-1011.1.

Kitrsidelli I.Y., Vlasov D.Y., Barantsevich E.P., Krylenkov V.A. \& Sokolov V.T. 2014. Kompleksy mikroskopičeskih gribov v počvah i gruntah poljarnogo ostrovo Izvestija Cik (Karskoje more). (Microfungi from soil of polar Island Izvestia tsik [Kara Sea].) Mikologiya i Fitopatologiya 48, 365-371.

Köchy M., Hiederer R. \& Freibauer A. 2015. Global distribution of soil organic carbon-part 1 : masses and frequency distributions of SOC stocks for the tropics, permafrost regions, wetlands, and the world. Soil 1, 351-365, doi: 10.5194/soil-1-351-2015.

Kolchugina T.P., Vinston T.S., Gaston G. G. Rozhkov V.A. \& Shwidenko A.Z. 1995. Carbon pools, fluxes and sequestration potential in soils of the former Soviet Union. In R. Lal (ed.): Soil management and greenhouse effect. Pp. 25-40. Boca Raton, FL: Lewis Publishers.

Koyama A., Wallenstein M.D., Simpson R.T. \& Moore J.C. 2014. Soil bacterial community composition altered by increased nutrient availability in Arctic tundra soils. Frontiers in Microbiology 5, article no. 516, doi: 10.3389/ fmicb.2014.00516.

Kuzyakov Y. 2011 . How to link soil C pools with CO2 fluxes? Biogeosciences 8, 1523-1537, doi: 10.5194/bg-8-1523-2011.

Lantz T., Gergel S. \& Henry G. 2010. Response of green alder (Alnus viridis subsp. fruticosa) patch dynamics and plant community composition to fire and regional temperature in north-western Canada. Journal of Biogeography 37, 1597-1610, doi: 10.1111/j.1365-2699.2010.02317.x.

Lauber C.L., Hamady M., Knight R. \& Fierer N. 2009. Pyrosequencing-based assessment of soil $\mathrm{pH}$ as a predictor of soil bacterial community structure at the continental scale. Applied and Environmental Microbiology 75, 5111-5120, doi: 10.1128/AEM.00335-09.

Li F., Chen L., Zhang J.B., Yin J. \& Huang S.M. 2017. Bacterial community structure after long-term organic and inorganic fertilization reveals important associations between soil nutrients and specific taxa involved in nutrient transformations. Frontiers in Microbiology 8, article no. 187, doi: 10.3389/fmicb.2017.00187.

Lubbe A. \& Smith R.V. 2012. Field soil respiration rate on a Subantarctic Island: its relation to site characteristics and response to added C, N and P. Open Journal of Soil Science 2, 187-195, doi: 10.4236/ojss.2012.22023.

Lupachev A.V., Gubin, S.V., Veremeeva, A.A., Kaverin, D.A., Pastukhov, A.V. \& Yakimov A.S. 2016. Microrelief of the permafrost table: structure and ecological functions. Kriosphera Zemli 20(2), 3-14.

Malard L., Anwar M., Jacobsen C. \& Pearce D. 2019. Biogeographical patterns in soil bacterial communities across the 
Arctic region. FEMS Microbiology Ecology 95(9), article no. fizl28, doi: 10.1093/femsec/fizl28.

Matsuura Y. \& Yefremov D.P. 1995. Carbon and nitrogen storage of soils in a forest-tundra area of northern Sakha, Russia. In K. Takahashi et al. (eds.): Proceedings of the third symposium on the joint Siberian permafrost studies between Japan and Russia in 1994. Pp. 97-101. Sapporo: Forest and Forest Products Research Unit.

Matyshak G., Bogatyreb L., Goncharova O. \& Bobrik A. 2017. Specific features of the development of soils of hydromorphic ecosystems in the northern taiga of western Siberia under conditions of cryogenesis. Eurasian Soil Science 50, 1115-1124, doi: 10.1134/S1064229317100064.

McGuire A.D., Anderson L.G., Christensen T.R., Dallimore S., Guo L., Hayes D.J., Heimann M., Lorenson T.D., Macdonald R.W. \& Roulet, N. 2009. Sensitivity of the carbon cycle in the Arctic to climate change. Ecological Monographs 79, 523-555, doi: 10.1890/08-2025.1.

Moore T.R. \& Basiliko N. 2006. Decomposition in boreal peatlands. In R.K. Wieder \& D.H. Vitt (eds.): Boreal peatland ecosystems. Pp. 125-143. Heidelberg: Springer.

Nadelhoffer K.J., Giblin A.E. \& Shaver A.E. 1992. Microbial processes and plant nutrient availability in Arctic soils. In F.S. Chapin III et al. (eds.): Arctic ecosystems in a changing climate: an ecophysiological perspective. Pp. 281-300. San Diego, CA: Academic Press.

Parry M., Canziani O., Palutikof J., van der Linden P. \& Hanson C. (eds.) 2007. Climate change 2007. Impacts, adaptations and vulnerability. Working Group II contribution to the fourth assessment report of the Intergovernmental Panel on Climate Change. Cambridge: Cambridge University Press.

Ping C.L., Michaelson G.J., Jorgenson M.T., Kimble J.M., Epstein H., Romanovsky V.E. \& Walker D.A. 2008. High stocks of soil organic carbon in the North American Arctic region. Nature Geoscience 1, 615-619, doi: 10.1038/ngeo284.

Ping C.L., Michaelson G.J. \& Kimble J.M. 1997. Carbon storage along a latitudinal transect in Alaska. Nutrient Cycling in Agroecosystems 49, 235-242, doi: 10.1023/A:100973 1808445.

Post W.M., Emanuel W.R., Zinke P.J. \& Stangenberger A.G. 1982. Soil carbon pools and world life zones. Nature 298, 156-159, doi: 10.1038/298156a0.

Quast C., Pruesse E., Yilmaz P., Gerken J., Schweer T., Yarza P., Peplies J. \& Glöckner F.O. 2013. The SILVA ribosomal RNA gene database project: improved data processing and web-based tools. Nucleic Acids Research 41(D1), D590-D596, doi: 10.1093/nar/gks1219.

Racine C., Jandt R., Meyers C. \& Dennis J. 2004. Tundra fire and vegetation change along a hillslope on the Seward Peninsula, Alaska, USA. Arctic, Antarctic, and Alpine Research 36, 1-10, http://doi.org/10.1657/1523-0430.

Rognes T., Flouri T., Nichols B., Quince C. \& Mahé F. 2016. VSEARCH: a versatile open source tool for metagenomics. PeerJ 4, e2584, doi: 10.7717/peerj.2584.

Rousk J., Baath E., Brookes P.C., Lauber C.L., Lozupone C., Caporaso J.G., Knight R. \& Fierer N. 2010. Soil bacterial and fungal communities across a $\mathrm{pH}$ gradient in an arable soil. ISME Journal 4, 1340-1351, doi: 10.1038/ ismej.2010.58.
Schepaschenko D.G., Mukhortova L.V., Shvidenko A.Z. \& Vedrova E.F. 2013. The pool of organic carbon in the soils of Russia. Eurasian Soil Science 46, 107-116, doi: 10.1134/ S1064229313020129.

Schimel J.P., Reynolds J.F., Tenhunen J.D., Kielland K. \& Chapin F.S. III 1996. Nutrient availability and uptake by tundra plants. In J. Reynolds \& J. Tenhunen (eds.): Ecological studies analysis and synthesis: landscape function and disturbance in Arctic tundra. Pp. 203-221. New York: Springer-Verlag.

Schnitzer M. 1982. Organic matter characterization. In A.L. Page et al. (eds.): Methods of soil analysis, part 2: chemical and microbiological properties. Pp.581-594. Madison, WI: American Society of Agronomy.

Schütz K., Kandeler E., Nagel P., Scheu S. \& Ruess L. 2010. Functional microbial community response to nutrient pulses by artificial groundwater recharge practice in surface soils and subsoils. FEMS Microbiology Ecology 72, 445-455, doi: 10.1111/j.1574-6941.2010.00855.x.

Shaver G.R., Bret-Harte M.S., Jones M. H., Johnstone J., Gough L. Laundre J. \& Chapin F.S. III 2001. Species composition interacts with fertilizer to control long-term change in tundra productivity. Ecology 82, 3163-3181, doi: 10.1890/00129658.

Siewert M.B., Hugelius G., Heim B. \& Faucherre S. 2016. Landscape controls and vertical variability of soil organic carbon storage in permafrost-affected soils of the Lena River Delta. Catena 147, 725-741, doi: 10.1016/j.catena. 2016.07.048.

Šijatov S.G. \& Mazepa V.S. 1995. Klimat. (Climate.) In L.N. Dobrinskij (ed.): Priroda Jamala. (Nature of Yamal.) Pp. 32-68. Ekaterinburg: Nauka.

Šišov L.L., Tonkonogov V.D., Lebedeva I.I. \& Gerasimova M.I. 2004. Klassifikacija I diagnostika počv Rossii. (Classification and diagnostics of soils of Russia.) Smolensk: Oykumena.

Smith C.A.S. \& Veldhuis H. 2004. Cryosols of the boreal, Subarctic, and western Cordillera regions of Canada. In J.M. Kimble (ed.): Cryosols. Permafrost-affected soils. Pp. 119-138. Berlin: Springer Verlag.

Stolbovoi V. 2002. Carbon in Russian soils. Climatic Change 55 , 131-156, doi: 10.1023/A:1020289403835.

Tarnocai C., Canadell J.G., Schuur E.A.G., Kuhry P. Mazhitova G. \& Zimov S. 2009. Soil organic carbon pools in the northern circumpolar permafrost region. Global Biogeochemical Cycles 23, GB2023, doi: 10.1029/2008GB003327.

Vlasov D., Abakumov E., Tomashunas V., Krylenkov V. \& Zelenskaya M. 2014. Micobiota počv i antropogennyh substratov poluostrova Jamal. (Mycobiota of soil and anthropogenic substrates of the Yamal Peninsula.) Gigiena i Sanitarija 5, 49-51.

Walker D., Leibman M., Epstein H., Forbes B., Bhatt U., Raynolds M., Comiso J., Gubarkov A., Khomutov A., Gia J., Kaarlejärvi E., Kaplan J., Kumpula T., Kuss T., Matyshak G., Moskalenko N., Orekhov P., Romanovsky V., Ukraientseva N. \& Yu Q. 2009. Spatial and temporal patterns of greenness on the Yamal Peninsula, Russia: interactions of ecological and social factors affecting the Arctic normalized difference vegetation index. Environmental Research Letters 4 , article no. 404500, doi: 10.1088/1748-9326/4/4/045004. 
Walz J., Knoblauch C., Bohme L. \& Pfeiffer E.-M. 2017. Regulation of soil organic matter decomposition in permafrost-affected Siberian tundra soils-impact of oxygen availability, freezing and thawing, temperature, and labile organic matter. Soil Biology e Biochemistry 110, 34-43, doi: 10.1016/j.soilbio.2017.03.001.

Wang Q., Garrity G.M., Tiedje J.M. \& Cole J.R. 2007. Naive Bayesian classifier for rapid assignment of rRNA sequences into the new bacterial taxonomy. Applied and Environmental Microbiology 73, 5261-5267, doi: 10.1128/AEM.00062-07.

Wolińska A., Kuźniar A., Szafranek-Nakonieczna A., Jastrzębska N., Roguska E. \& Stępniewska Z. 2016. Biological activity of autochthonic bacterial community in oilcontaminated soil. Water, Air, and Soil Pollution 227, article no. 130, doi: 10.1007/s1 1270-016-2825-z.

Wolińska A., Gałazka A., Kuzniar A., Goraj W., Jastrzębska N., Grzadziel J. \& Stepniewska Z. 2018. Catabolic fingerprinting and diversity of bacteria in Mollic Gleysol contaminated with petroleum substances. Applied Sciences 8, article no. 1970, doi: 10.3390/app8101970.

Yan Y., Kuramae E.E., Klinkhamer P.G. \& van Veen J.A. 2015. Revisiting the dilution procedure used to manipulate microbial biodiversity in terrestrial systems. Applied and Environmental Microbiology 81, 4246-4252, doi: 10.1128/ AEM.00958-15.

Zimov S.A., Schuur E.A.G. \& Chapin F.S. III 2006. Permafrost and the global carbon budget. Science 312, 1612-1613, doi: 10.1126/science.1128908.

Zubrzycki S., Kutzbach L., Grosse G., Desyatkin A. \& Pfeiffer E.-M. 2013. Organic carbon and total nitrogen stocks in soils of the Lena River Delta. Biogeosciences 10, 3507-3524, doi: 10.5194/bg-10-3507-2013.

Zubrzycki S., Kutzbach L. \& Pfeiffer E.-M. 2014. Permafrost-affected soils and their carbon pools with a focus on the Russian Arctic. Solid Earth 5, 595-609, doi: 10.5194/ se-5-595-2014. 